\title{
IDENTIFICATION AND FOLLOW-UP OF CHILDREN WITH HEARING LOSS IN MAURITIUS
}

BY

RACHNA GOPAL

In partial fulfilment of the requirements

for the degree M.Communication Pathology

in the Department of Communication Pathology

University of Pretoria

October 1999 


\section{SUMMARY}

TITLE: IDENTIFICATION AND FOLLOW-UP OF CHILDREN WITH HEARING LOSS IN MAURITIUS

NAME: $\quad$ RACHNA GOPAL

LEADER: $\quad$ PROF R HUGO

CO-LEADER: PROF B LOUW

DEPARTMENT: COMMUNICATION PATHOLOGY

UNIVERSITY OF PRETORIA

DEGREE: M. COMMUNICATION PATHOLOGY

Early identification of hearing loss followed by a timely and effective intervention programme for children with hearing impairment is necessary to minimise the negative effects of hearing loss on the development of cognition, psychosocial and verbal communication skills. Such early intervention programmes need to be multidisciplinary, technologically sound and take cognisance of the context in which the child and family function.

The main aim of this study is to obtain accurate and reliable baseline information regarding current status of the intervention process for children with hearing loss in Mauritius, a developing country. An exploratory, descriptive qualitative research design is selected to achieve this aim. Questionnaire-based interviews were carried out to obtain information from 37 hearing impaired children's parents regarding the median ages of suspicion of hearing loss, diagnosis and placement of hearing aids. The referral 
process, diagnosis and the management of these children is described.

The findings indicate that children in the study were identified late [median age 24 months] and that the management process is fragmented. The strengths in the current identification and followup process namely, parental involvement and established public service structure are highlighted. The weaknesses in the current system are identified, for example, time lapses in identification process, provision of hearing aids and lack of co-ordinated services.

The theoretical and empirical research carried out forms the basis of recommendations that have practical implications for an early intervention programme for children with hearing loss in Mauritius.

Key words: Pre-lingual hearing loss; Prevention; Screening; Age of suspicion of hearing loss; Early intervention; Age of diagnosis of hearing loss; Management of hearing loss; Mainstreaming; Communication skills. 


\section{OPSOMMING}

Vroeë identifikiasie van gehoorverlies gevolg deur ' $n$ tydige en effektiewe intervensieprogram by kinders met ' $n$ gehoorverlies is noodsaaklik om die negatiewe invloed van gehoorverlies op kognitiewe ontwikkeling, psigososiale en verbale kommunikasievaardighede so gering as moontlik te maak. Sodanige vroeë intervensieprogramme moet multidissiplinêr en tegnologies weldeurdag wees en moet die konteks waarbinne die kind en sy gesin funksioneer in aanmerking neem.

Die hoofdoel van hierdie studie is om akkurate en betroubare basislyninligting in te samel oor die huidige status van die intervensieproses by kinders met ' $n$ gehoorverlies in Mauritius, wat ' $n$ ontwikkelende land is. Om hierdie doelstelling te bereik is in Ondersoekende, beskrywende kwalitatiewe navorsingsontwerp is gekies. Onderhoude gebaseer op vraelyste is uitgevoer om inligting te verkry van die ouers van 37 kinders met gehoorverlies. Die inligting het sentreer rondom die gemiddelde ouderdomme waarop gehoorverlies vermoed is, diagnose en passing van gehoorapparate. Die verwysingsproses, diagnose en behartiging ten opsigte van hierdie kinders word beskryf.

Die bevindinge dui aan dat die kinders wat by die studie betrek was, laat geïdentifiseer is (gemiddelde ouderdom 24 maande) en dat die behartigingsproses gefragmenteerd is. Die serk punte in die huidige identifikasie- en opvolgproses word uitgelig en die swak punte word geïdentifiseer. Die teoretiese en empiriese navorsing wat uitgevoer is vorm die basis vir aanbevelings wat praktiese 
implikasies het vir 'n program van vroeë intervensie by kinders met 'n gehoorverlies in Mauritius.

Sleutelwoorde: Prelinguale gehoorverlies; voorkoming sifting ouderdom waarop gehoorverlies vermoed word; vroeë intervensie; ouderdom waarop gehoorverlies gediagnoseer word; behartiging van gehoorverlies; hoofstroming; kommunikasievaardighede. 


\section{Acknowledgements}

I would like to extend my sincere thanks to the following:

- Prof R Hugo and Prof B Louw, for their motivation and guidance

- Ministry of Health and Quality of Life, Mauritius, for supporting the research project

- WHO, Mauritius, for the support with literature research

- UNICEF, Mauritius for their financial support

- Mr Amihere for his patience and guidance

- My family for their love and support 


\section{Contents}

TITLE

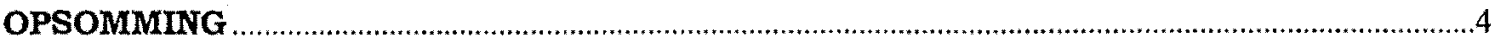

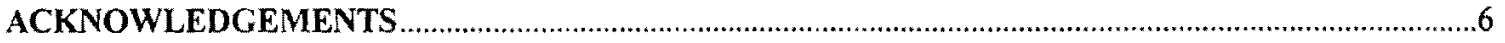

CHAPTER 1 ORIENTATION AND STATEMENT OF THE PROBLEM ………............................... 11

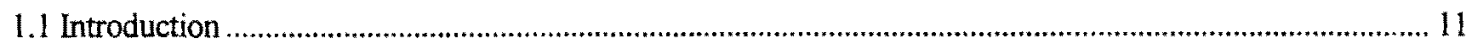

1.2 Background to Problem Statement: Early Identification ............................................................................. 13

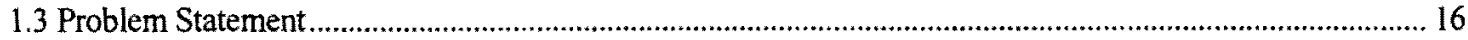

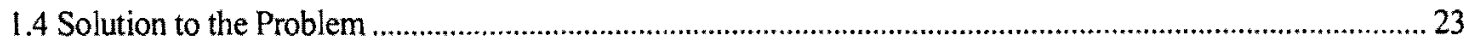

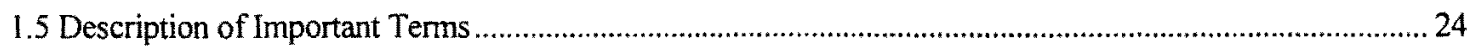

1.6 Outline of Chapters

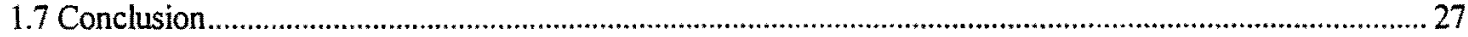

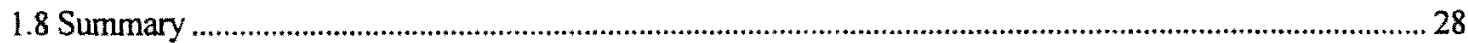

CHAPTER 2 EARLY INTERVENTION FOR CHILDREN WITH HEARING LOSS .......................... 31

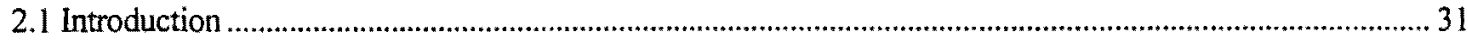

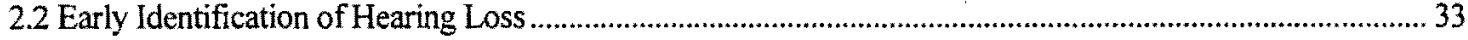

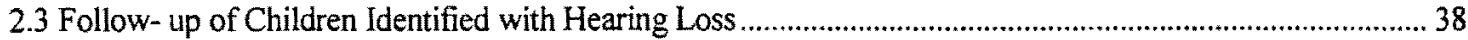

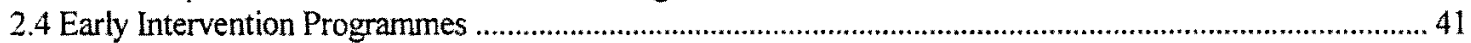

2.5 Focus on Early Intervention for Children with Hearing Loss in Developing Countries ...................................44

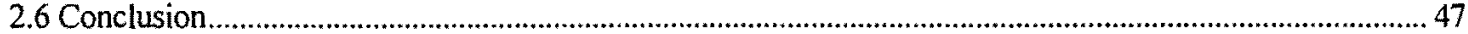

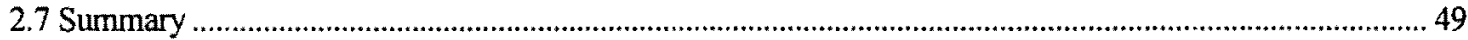

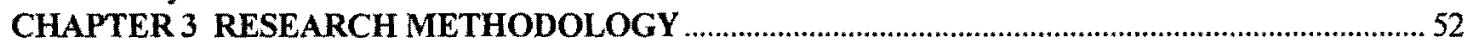

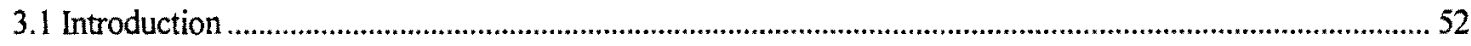

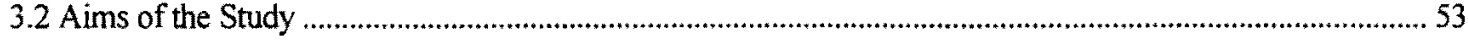

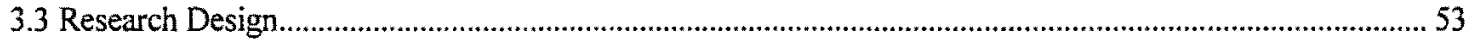

3.4 Research Sampling Procedure

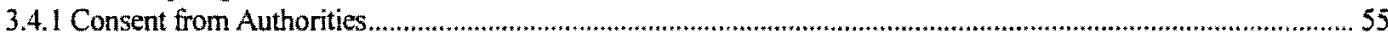

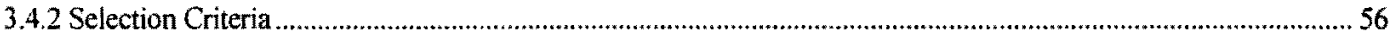

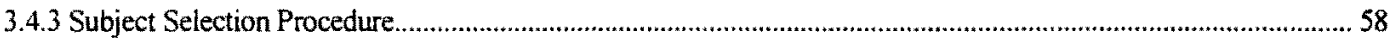

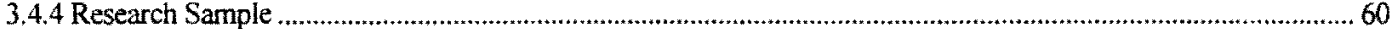

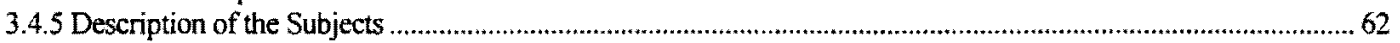

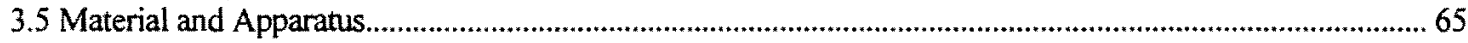

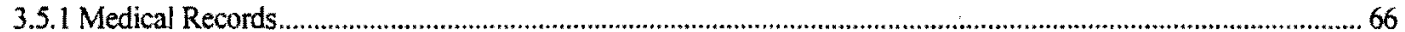

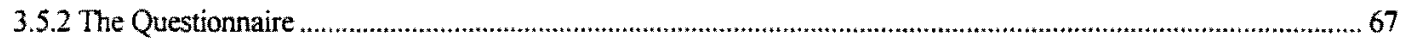

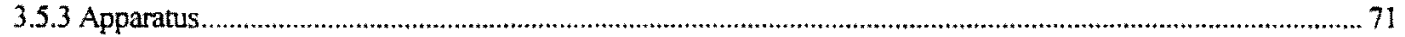

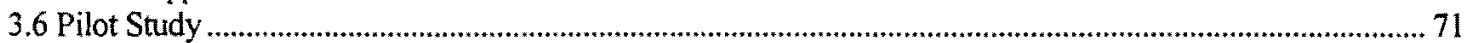

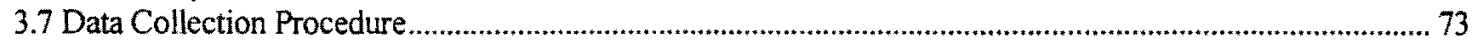

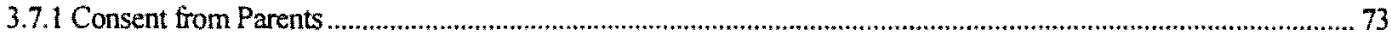

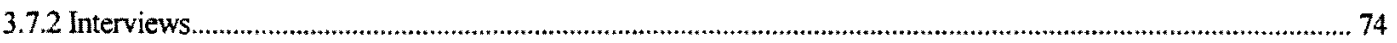

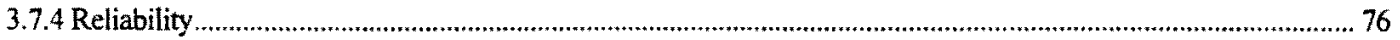

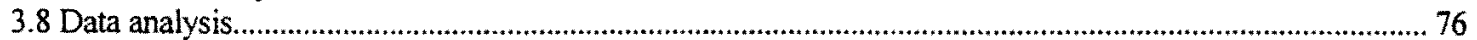

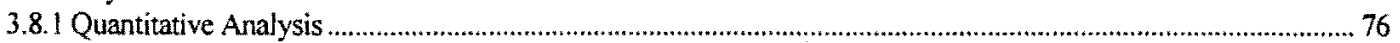

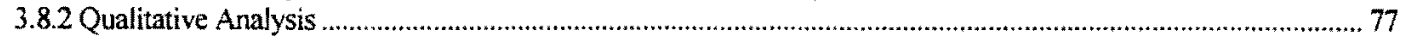

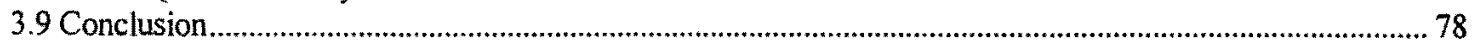

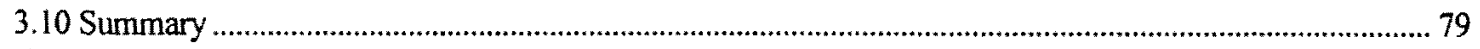

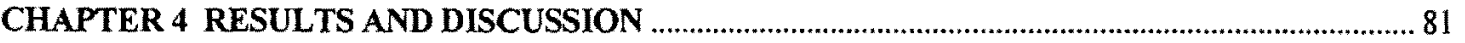

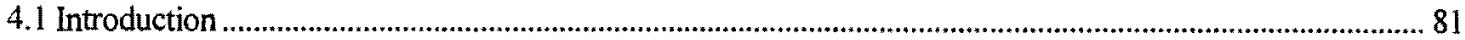

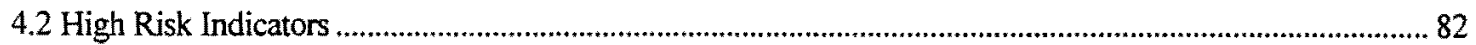

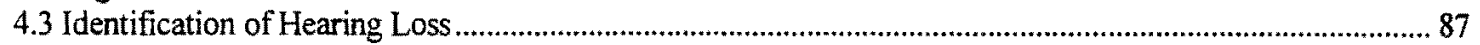

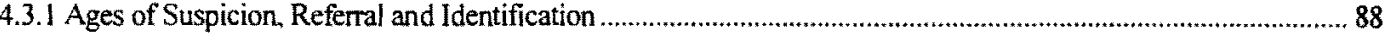

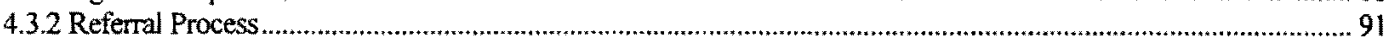

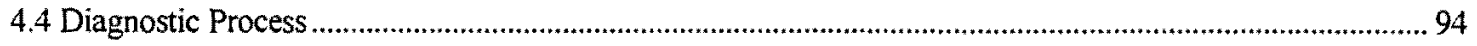




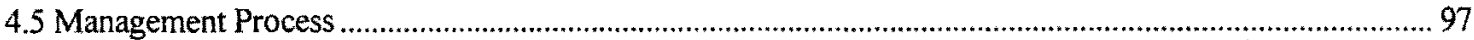

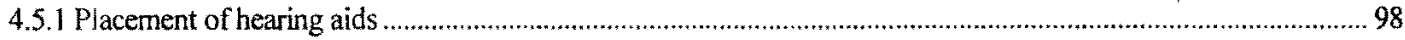

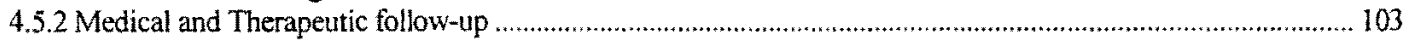

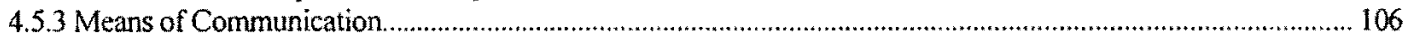

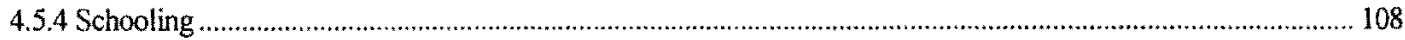

4.6 Relationship between aspects of suspicion, identification, management of hearing loss and biographical

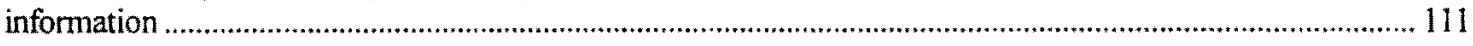

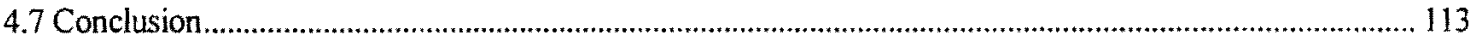

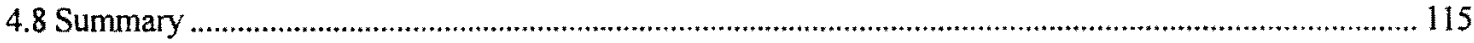

CHAPTER 5 CONCLUSIONS AND RECOMMENDATIONS ........................................................ 117

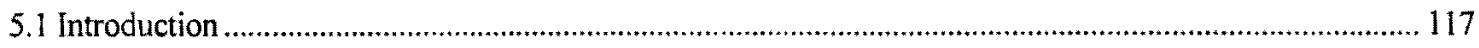

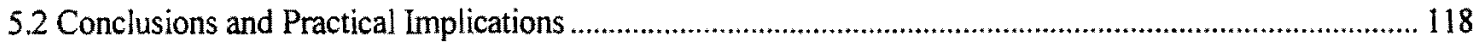

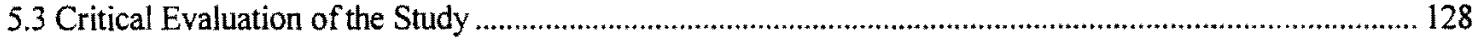

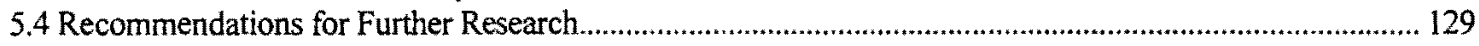

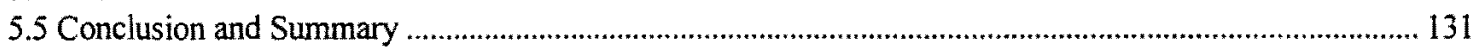

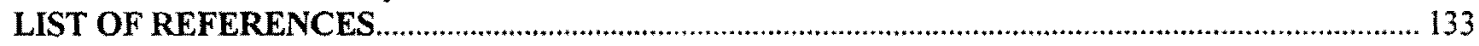

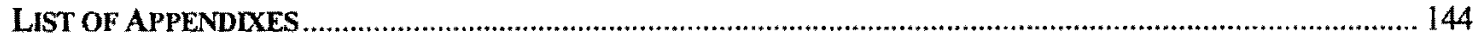

Appendix A Letter for consent from the Health Authorities .................................................................... 145

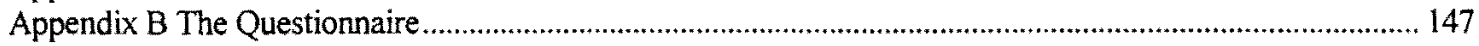

Appendix C Listing of Indicators or High Risk Factors Associated with Sensorineural Hearing Loss ............ 153

Appendix D Letter inviting the parents of the children with hearing impairment for a meeting .................... 154

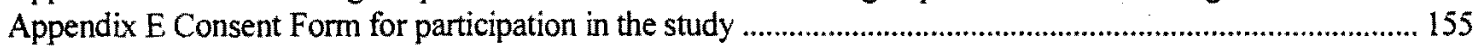

\section{LIST OF FIGURES}

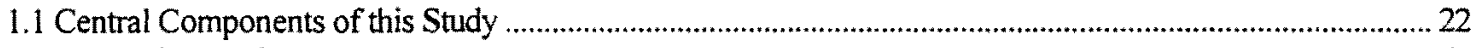

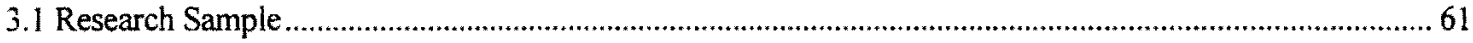

\section{LIST OF TABLES}

2.1 Studies in USA pertaining to Identification of Hearing Loss among children ..........................................34

2.2 Studies in UK pertaining to Identification of Hearing Loss among children .............................................. 35

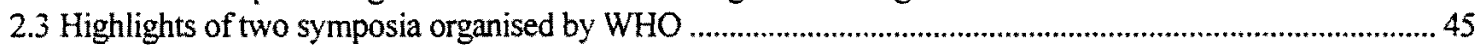

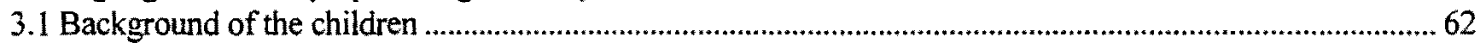

3.2 Number of children in the family and the position of the child ...................................................................62

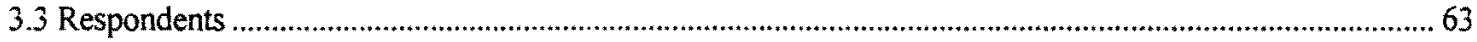

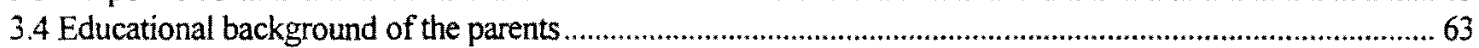

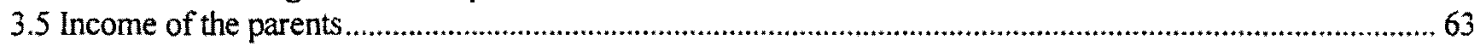

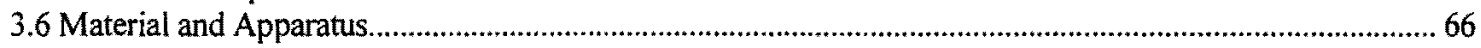

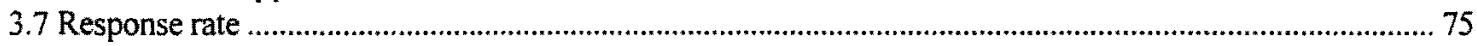

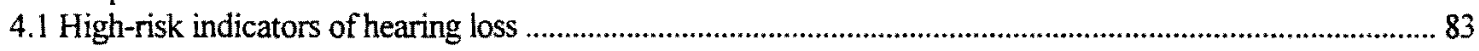

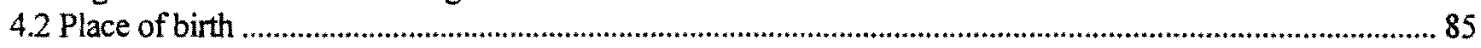

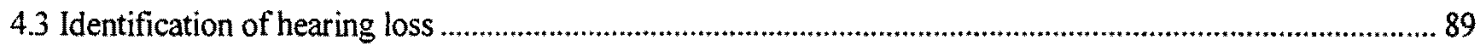

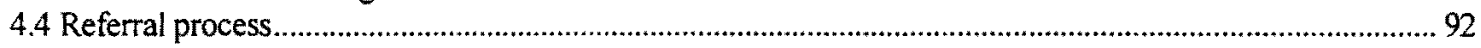

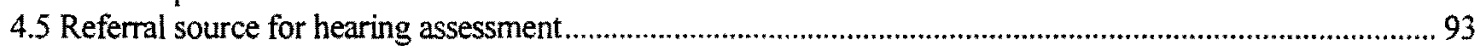

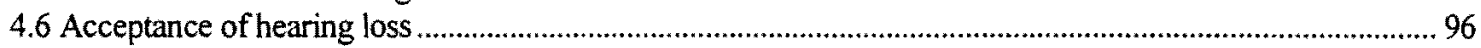

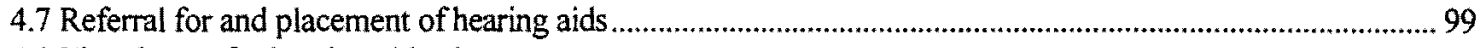

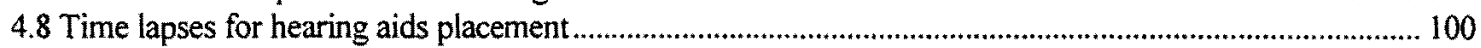

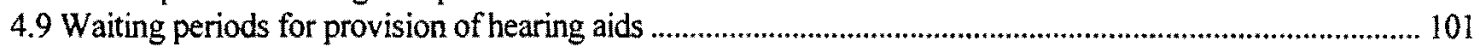

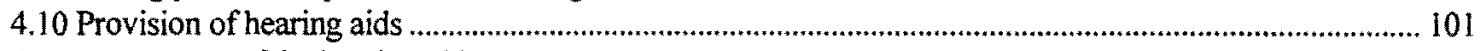

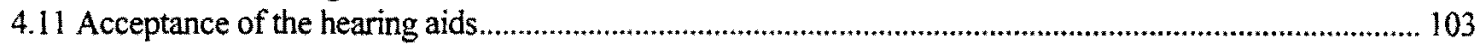

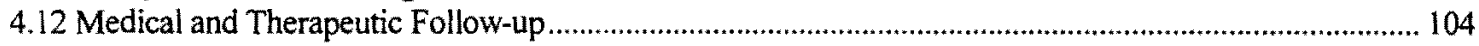

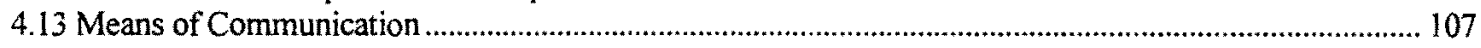

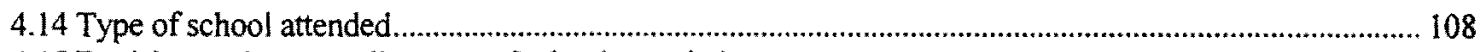

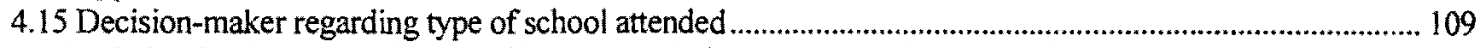

4.16 Relationship between educational background of the parents and the age of suspicion of hearing loss.... 111 4.17 Time lapse between identification of hearing loss and placement of hearing aids according to parental income 